\title{
SmartWUDHU': Recycling Ablution Water for Sustainable Living in Malaysia
}

\author{
Azeanita Suratkon ${ }^{1}$, Chee Ming Chan ${ }^{2} \&$ Tengku Syamimi Tuan Ab Rahman ${ }^{3}$ \\ ${ }^{1}$ Faculty of Civil \& Environmental Engineering, Universiti Tun Hussein Onn Malaysia, Malaysia \\ ${ }^{2}$ Faculty of Engineering Technology, Universiti Tun Hussein Onn Malaysia, Malaysia \\ ${ }^{3}$ Faculty of Civil \& Environmental Engineering, Universiti Tun Hussein Onn Malaysia, Malaysia \\ Correspondence: Azeanita Suratkon, Faculty of Civil \& Environmental Engineering, Universiti Tun Hussein Onn \\ Malaysia, 86400 Parit Raja, Batu Pahat, Johore, Malaysia. Tel: 60-7-456-4226. E-mail: azeanita@uthm.edu.my
}

Received: October 8, 2014 Accepted: October 29, 2014 Online Published: November 23, 2014

doi:10.5539/jsd.v7n6p150 URL: http://dx.doi.org/10.5539/jsd.v7n6p150

\begin{abstract}
The ablution ritual consumes large amount of water, especially in musollas and mosques, where the greywater is allowed to run free and drain away. As quoted in the Hadith, Prophet Muhammad reminded Muslims to avoid wastage, even when performing the cleansing ritual or ablution prior to prayer. The ritual, locally known as known as wudhu', requires a Muslim to wash exposed body parts with clean water. In Malaysia, most ablution system consists simply of a row of water taps with a drainage trough to carry the greywater to main drains. As the tap is usually left running, much good water is wasted in the process. Considering the unnecessary wastage, a simple recycling system can be designed to collect, treat and reuse the ablution water within a close-loop system for non-potable water applications, such as toilet flushing, general washing, plants watering and flowerbed cultivation. This approach does not only introduce practical engineering solutions in promoting sustainable living, it is also in-line with the Islamic principles of using natural resources in a prudent manner. By referring the University's own mosque, a study was conducted to develop and verify a conceptual model of the ablution water recycling system, named SmartWUDHU', which fulfills the requirements of Islamic teachings yet viable from the engineering perspective. A simple ablution water output prediction model was next proposed to more accurately quantify the capacity and efficiency of the close-loop water recycling system. Water quality check was also carried out to gauge the effectiveness of treatment against regulated standards as well as religious provisions. The SmartWUDHU' system, retrofitted or installed new, exemplifies a successful merge between engineering know-how and religious doctrines for enhanced quality living now, and into the future.
\end{abstract}

Keywords: greywater recycling, water wastage, Islamic perspective, recirculation efficiency

\section{Introduction}

The ablution ritual usually takes up several minutes at a running water facility, allowing a considerable amount of water to go to waste when only handfuls of water are collected and used at each step of the ritual (Tuan Ab Rahman, 2008). Consequently, the ritual, when performed en masse in musollas and mosques, especially during the Friday prayers, entails significant wastage of treated water (Prathapar et al., 2004).

From the religious point of view, did the Almighty Allah not declare that He does not love the wasters: "O children of Adam, take your adornment (by wearing your clean clothes), while praying and going round (the Tawaf of) the Ka'bah, and eat and drink, but waste not by extravagance, certainly He (Allah) likes not those who waste by extravagance" (The Noble Qu'ran, Al-A'raf, 7:31). This is a clear reminder to Muslims to always practice moderation and conservation with a heightened sense of gratitude (syukur). As reported by Ibn Majah, the Prophet, on seeing a man performing the ablution ritual by a river in a wasteful manner, has declared in answer to the man's question of israaf (wastefulness or wastage) in wudhu': "Yes indeed, (do not waste) even if you perform them on the bank of a rushing river" (Ibn Majah - Book 2, Hadith 425). These records explicitly indicate the need to review and improve, if possible, the current practice of performing the ablution ritual, specifically in the aspect of water conservation.

Greywater generated from the ablution ritual is relatively clean as it contains no soap or solid impurities, but small amounts of microorganisms mainly from gargling. Hence by capturing this marginally contaminated water 
and channeling it through basic treatment, the water can be recycled and reused in non-potable water applications. The treated water can be used indoor for flushing toilet bowls and general washing, while outdoor applications include irrigation of flowerbeds, plant nurseries as well as car-washing. All these clearly show how the ablution water can be reused in beneficial ways with a close-loop water recycling system. Similar efforts to reuse the ablution water were reported by Abu Rizaiza (2002), Al-Wabel (2011) and Al Mamun et al. (2012). As the ablution water is essentially a lightly contaminated grey water, techniques to capture and recycle other greywater are also potentially applicable to the ablution water (e.g. Erikkson et al., 2003, March et al., 2004, Pinto and Maheshwari, 2010, Yousefi et al., 2013 and Rana et al., 2014).

It was in this direction that the present study was conducted, with an attempt to develop a feasible model of the system, named SmartWUDHU'. By examining the engineering features and components concurrently with the review of the religious interpretation of 'pure' water for ablution, a common ground was defined to meet both sets of requirements in providing an effective system. A framework of the approach adopted in this dual-pronged study is shown in Figure 1.
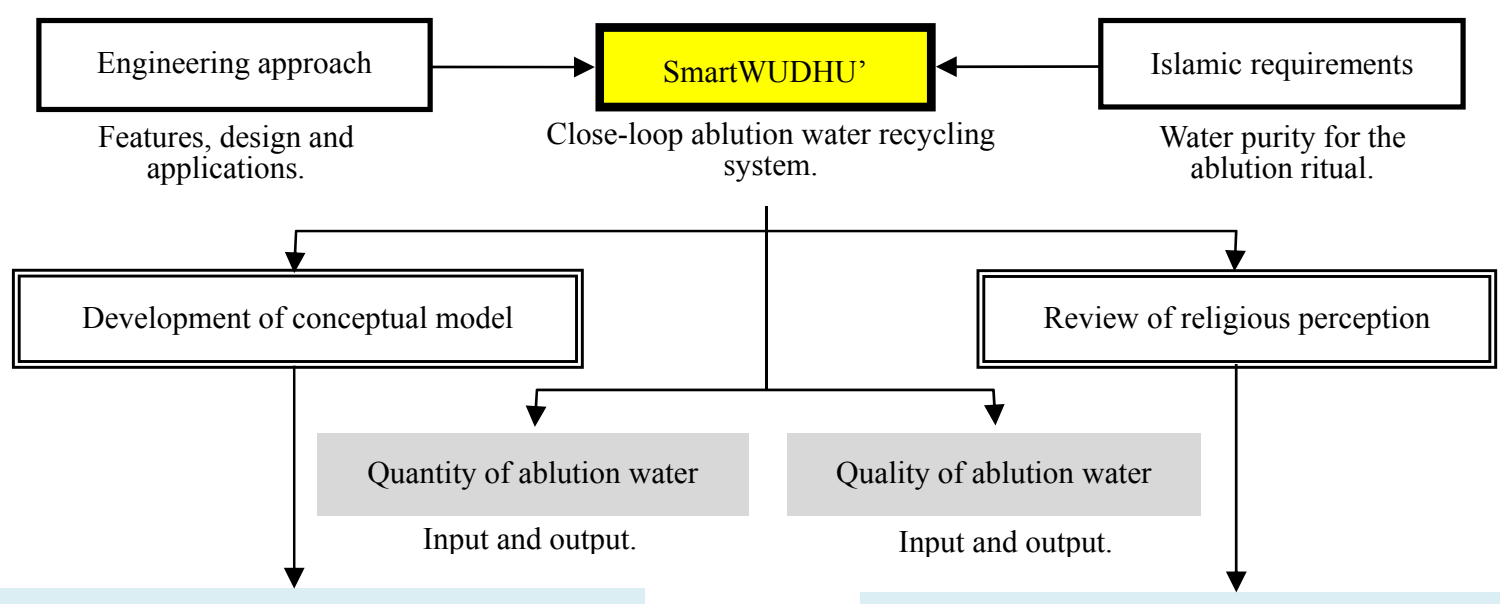

Engineering components and features to make the system viable in a sustainable way.

Usul Fiqh (religious) analysis and verification for possible revolutionary outcome.

Figure 1. Framework of study for development of SmartWUDHU'.

Essentially the SmartWUDHU' system consists of an input and output sections. The input section directs the used ablution water into a catchment, which is then transferred to a storage tank with chlorine treatment device. The output section, on the other hand, channels the treated water from the storage tank to both indoor and outdoor applications through suitable piping network. It is not too difficult to assemble the individual components in the system, but to have it running efficiently requires good engineering judgment and design.

\section{Fundamentals of the Study}

\subsection{Definition of the Conceptual Model}

A conceptual model for SmartWUDHU', which embodies the relevant Islamic values, was designed to illustrate the water flow and components in the system. The model was designed to suit both new installations as well as for retrofitting works. New installations are apparently more straightforward with the direct adoption of a design layout, whereas retrofitting requires more modifications and adaptations to suit the existing plumbing configurations, and space limitations, for instance.

In general, the SmartWUDHU' consists of the following main components: ablution water collection and storage, filtration unit, chlorine dispenser and treated water collection tank (Figure 2). Circulation of the water, be it treated or untreated, would be fully automated with the aid of sensors and pumps in a close-loop flow network. Suitable pipes and fittings would be installed to deliver the water within the building and for external usage. The close-loop system has the advantage of minimizing water wastage via greywater discharge, as well as avoiding contamination from external sources (Bakir et al., 2001). 


\subsection{Close-loop Flow of the SmartWUDHU'}

The primary source of water for the system is the ablution area, where greywater from the ritual is collected in a temporary storage trough beneath the washing bay. The greywater is next filtered to remove sediments and other fine particles before being pumped into an elevated storage tank. Filtration is an essential a pre-treatment to remove large suspended solids, ensuring the pump efficiency and avoiding clogging. Once transferred to the storage tank, sedimentation would take place to further cleanse the water of finer particles. At the same time, disinfection of the water would be effected through chlorination using an automated dispenser fixed to the tank. The treated water is now ready to be distributed indoors or outdoors for various purposes other than ingestion.

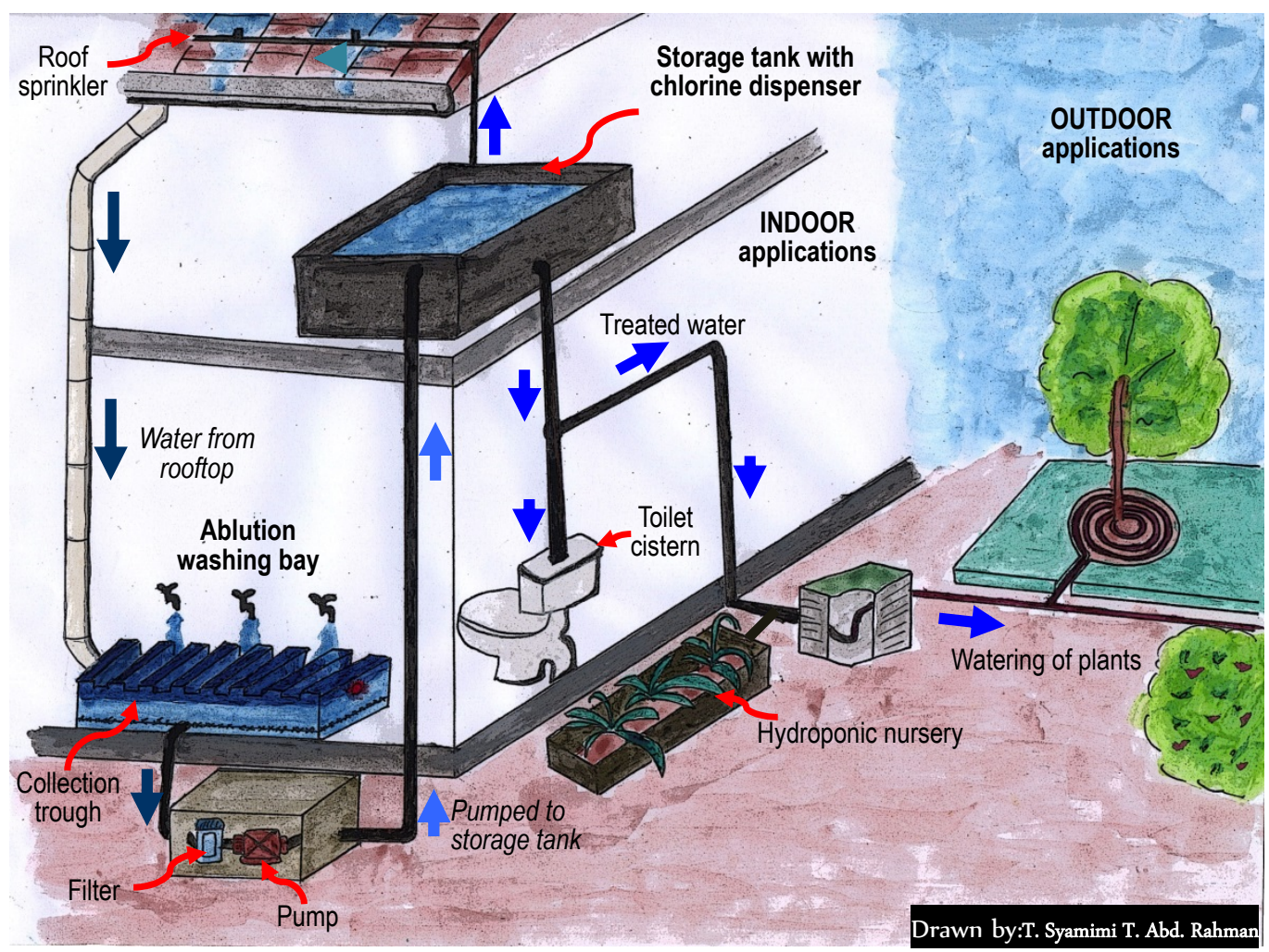

Figure 2. Artist's impression of SmartWUDHU' incorporated in a mosque

With a simple collection and connecting system, rain water can also be harvested from rooftops and added to the water supply of the system. This allows a larger volume of water supply for various indoor and outdoor applications. Directing water for reuse purposes to a central treatment system such as this is not novel, as proposed by Dixon et al. (1999) and Loux et al. (2012).

\subsection{Using Recycled Ablution Water from the Islamic Perspective}

The practical feasibility of treating and reusing this greywater for ablution purposes is not without potential issues and questions from the religious point of view. A major concern of the Muslim community in using this recycled water from the ablution ritual lies in the purity of the water itself. This is particularly critical when the recycling system is to be implemented in a house of worship, for example, where the recycled water, ideally, can and will be reused for performing the ablution ritual. This is an ideal concept, as the close-loop circulation system would have a common input and output points, i.e. retrieved from the ablution area and redistributed back to the same ablution area.

According to the basic rule of Fiqh, used water is termed Musta'mal water, where the water is still considered pure, but it cannot be used for purification purposes, i.e. ablution ritual. On the other hand, a water sample remains "pure" as long as its taste, colour and smell have not noticeably changed (Singapore Islamic Council, 2007). Therefore, if a treatment method can restore the taste, colour and smell of the used, "impure" water to its original condition, then the used water can be considered purified and hence usable for the ablution ritual. 
Based on the Usul Fiqh analysis (Maslahah Mursalah - Considerations of Public Interest) conducted, avoiding wastage in all manners effectively contributes to the good of public interest, especially in creating a cleaner, healthier and sustainable living environment. Referring to the analytical method, the use of recycled water for ablution purposes fulfills the criteria set forth by the religion, therefore effectively putting the issues on purity of the water at rest (Yahya and Fatchurrahman, 1993).

A relevant point of reference is the recycled wastewater system introduced in Singapore, i.e. Newater. The Mufti (religious head) of Singapore explicitly pronounced the acceptability of Newater from a Muslim's standpoint. The arguments put forth revolved around the 3 rudimentary methods of restoring the pureness of used water for Muslim's usage, namely (1) natural change by time, sun or blowing of wind, (2) change by the addition of clean water, and hence dilution, as well as (3) change by removal of apparent filth from the used water. However, it is also noted that these cleansing or purification processes would only restore the characteristics of pureness to the water on condition that the amount of water post-cleansing must be equivalent to 2 qullahs (water tank), which is approximately 270 litres in conventional terms (Singapore Islamic Council, 2007).

Locally, similar doubts on the appropriateness of the recycled water for Muslim's use were expressed in public domains too. To quote a typical case, in answer to a question in the "Tanya Pakar" or "Ask the Expert" column of the Harian Metro newspaper, the expert opinion corresponded with that mentioned above, i.e musta'mal water can be reused for ablution purposes as long as the cleansed water is no less than 270 litres (My Metro, 2008).

This requirement to ensure pureness of the recycled water for ablution rituals has been taken into consideration for designing the SmartWUDHU' storage and dispensing units, where the treated, recirculated water is discharged from a volume of no less than required 2 qullahs or 270 litres. Furthermore, the filtration and chlorination processes will effectively remove all biological pathogens and impurities from the greywater. Incorporation of these considerations in the design does not only make SmartWUDHU' more efficient from the technical point of view (as discussed further in section 3.3), but also makes the innovation in-line with the Fiqh's law.

\section{Results and Discussion}

In the Results section, summarize the collected data and the analysis performed on those data relevant to the discourse that is to follow. Report the data in sufficient detail to justify your conclusions. Mention all relevant results, including those that run counter to expectation; be sure to include small effect sizes (or statistically nonsignificant findings) when theory predicts large (or statistically significant) ones. Do not hide uncomfortable results by omission. Do not include individual scores or raw data with the exception, for example, of single-case designs or illustrative examples. In the spirit of data sharing (encouraged by APA and other professional associations and sometimes required by funding agencies), raw data, including study characteristics and indivldual effect sizes used in a meta -analysis, can be made available on supplemental online archives.

\subsection{Recruitment}

Provide dates defining the periods of recruitment and follow-up and the pnmary sources of the potential subjects, where appropriate. If these dates differ by group, provide the values for each group.

In order to support the application of the SmartWUDHU' system, 2 primary and fundamental components were examined: the estimation of quantity of water at the collection point, and the determination of the quality of the recycled ablution water.

\subsection{Quantity of Ablution Water: Estimation Model}

As a pilot study, the University's mosque was chosen as the target model in the present study. As in any public buildings, specifically in a Muslim's house of worship, the mosque's water usage ranged from the ablution ritual, general washing and cleaning as well as watering of surrounding landscape plants.

According to Abd Hafiz (2009), muezzin of the mosque, the number of worshippers in a day may vary from a small number to several hundreds, depending on the working and lecture schedules at the University. Nonetheless, an influx of worshippers on Friday noon time (mid-day mass prayer) was as expected. Table 1 summarises the survey outcome on the number of worshippers for a typical week.

Based on the information in Table 1, the ablution water consumption for a month can be estimated by using the following equation:

Number of mosque's user per week $\times 4$ weeks $\times$ ablution water volume used per person

$=4325$ persons $/$ week $\times 4$ weeks $\times * 5.0$ litres 
$=86500$ litres/month

\section{$=86.5 \mathrm{~m}^{3} /$ month}

*5.0 litres was the average volume of water required for a single ablution ritual, obtained by monitoring a number of users of the mosque at various prayer times in a day.

On average, $3.10 \mathrm{~m}^{3}$ of water is required for the ablution ritual alone in the mosque for a day. In comparison with a normal domestic indoor usage per day of $0.26 \mathrm{~m}^{3}$ (Water Research Foundation, 1999), the ritual clearly necessitates almost 12 times more water requirement. Notwithstanding the public access to a mosque, this relatively high water demand and the resulting greywater generated do relate to the religious teachings of Muslims to avoid wastage at all costs. Besides, Prophet Muhammad was reported to use 1 mudd of water (equal to $2 / 3$ litres) to perform the ablution ritual, and $1 s a$ ' up to 5 mudds (equal to $2-3 \frac{1}{2}$ litres) for a bath (Al-Bukhari

- Book 4, Hadith 200). This is surely in stark contrast to what is used today!

Table 1. Typical daily attendance at the University's mosque

\begin{tabular}{lcccccc}
\hline Days & Prayer Time & Subuh(Dawn) & $\begin{array}{c}\text { Asar } \\
\text { (Mid-day) }\end{array}$ & $\begin{array}{c}\text { Maghrib } \\
\text { (Late afternoon) }\end{array}$ & $\begin{array}{c}\text { Isyak } \\
\text { (Sightfall) }\end{array}$ & Total \\
\hline Monday & 50 & 175 & 175 & 100 & 100 & 600 \\
Tuesday & 50 & 175 & 175 & 100 & 100 & 600 \\
Wednesday & 50 & 175 & 175 & 100 & 100 & 600 \\
Thursday & 50 & 175 & 175 & 100 & 100 & 600 \\
Friday & 50 & 1000 & 175 & 100 & 100 & 1425 \\
Saturday & 50 & 50 & 50 & 50 & 50 & 250 \\
Sunday & 50 & 50 & 50 & 50 & 50 & 250 \\
\hline
\end{tabular}

Considering that the used ablution water is not highly polluted, it is indeed a dismal waste to channel the greywater for discharge instead of recycling it. This is not dissimilar to efforts directed at collecting and reusing mosque's greywater (e.g. Prathapar et. al, 2004, CSBE, 2003 and Al-Wabel, 2011), which if collectively done, can bring immense long term conservation benefits to the already depleting clean water resources. More importantly, the practice would align a Muslim's daily life routine with one of the more subtle yet essential religious tenets: to conserve and to not waste.

\subsection{Assessing the Efficiency of SmartWUDHU,}

For this exercise, a combination of ablution and rain water captured at the University's mosque was used as the basis for analysis. This combined volume of water is considered as potentially salvageable and reused for various non-potable purposes through the recycling system provided by SmartWUDHU'.

With the application of SmartWUDHU', it is estimated that a much reduced 1500 liters of supplied water is required compared to 3500 liters recorded for the existing system used (Figures 3 and 4). This is over $55 \%$ savings, which consequently contributes significantly to clean water conservation in the mosque. Days during dry spells with no rain were also taken into account for the feasibility of SmartWUDHU'. In such cases, the depleted source water will be compensated by intake of fresh, clean water supply from the mains. This can be achieved by a simple twin-storage tank design, one for the captured greywater and the other for fresh water from the mains, synchronized with a multi-valved control mechanism. This second stage improved design of SmartWUDHU' is currently being studied for its workability in application.

Essentially, in the attempt to produce $100 \%$ recycled water, efficiency of the existing, conventional water supply system in the mosque will not be compromised. In other words, there will not be a disruption in regular water supply for users of the place. Indeed, the newly introduced system allows for extra storage water for emergencies, such as a temporary termination of the water supply from the mains due to various technical matters, e.g. a burst pipe, regulated water supply because of a drought, etc. Besides, additional features can be derived from the recycled non-potable water for aesthetic or occupant's comfort applications. A decorative fountain and an automated watering system for ornamental plants in the mosque surrounding can be installed for the former 
purpose, while a roof sprinkler to cool down the open rest area of the mosque on hot days fits the latter.

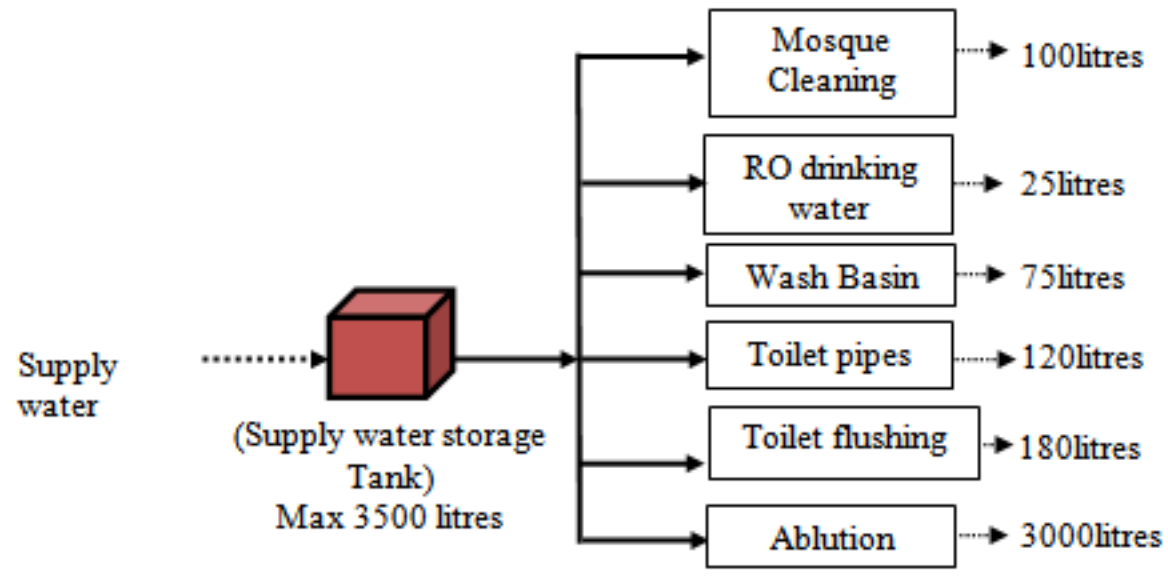

Figure 3. Existing water circulation network of the University's mosque

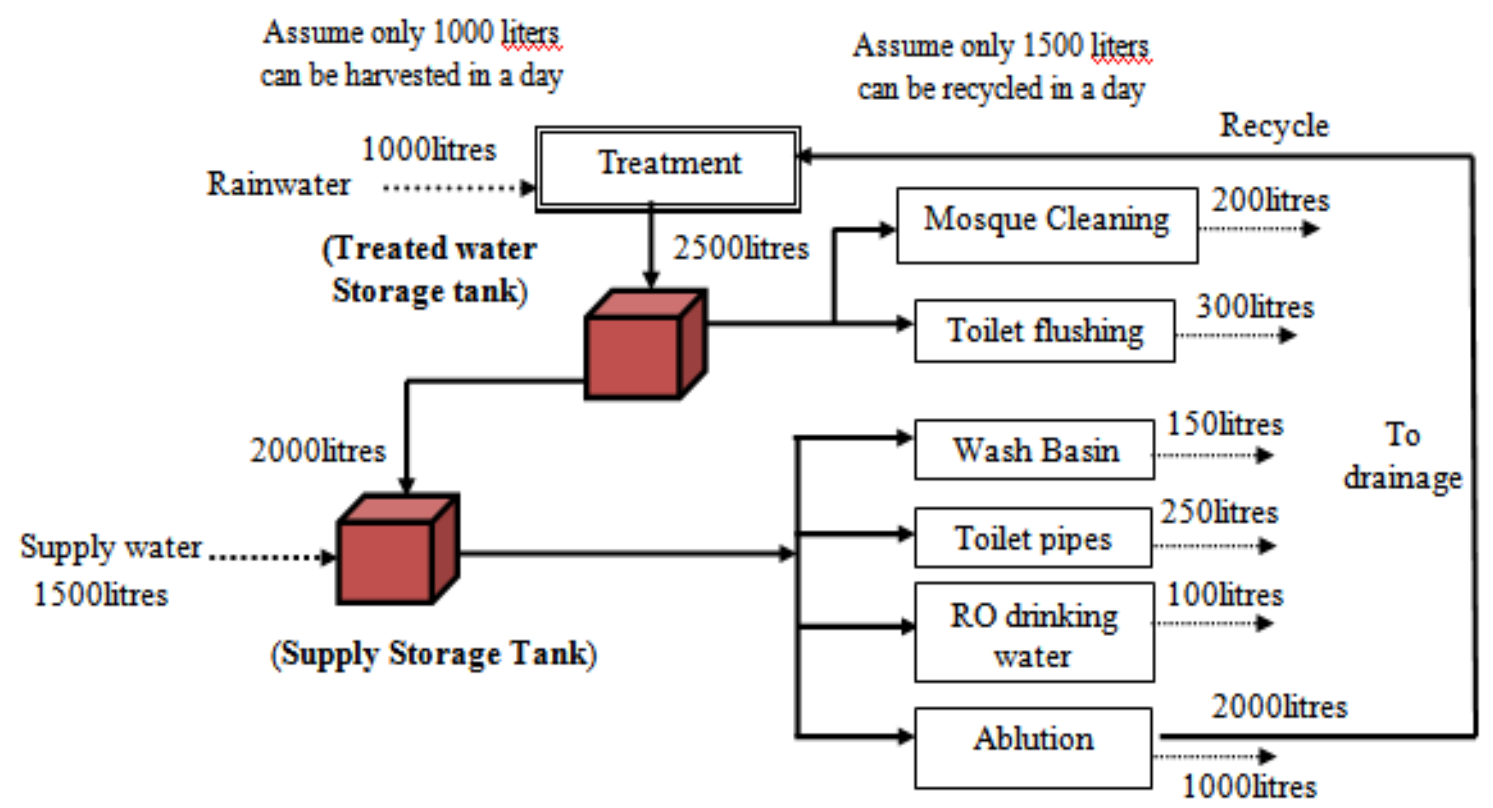

Figure 4. Proposed water circulation network of the University's mosque, incorporating the SmartWUDHU' system

\subsection{Analysis of Recycled Ablution Water Quality}

Although ablution water is relatively clean as it contains no soap or solid impurities, but only small amount of microorganisms, the greywater still requires treatment before it can be safely reused, even for non-potable purposes. To gauge the water quality, the following parameters were examined for samples taken from the ablution water, pre- and post-treatment: $\mathrm{pH}$, total coliform, E-Coli, turbidity, residue chlorine and total chlorine. Conventional laboratory water quality measurement apparatus were used to carry out the assessment. Results of the water quality check on both water samples are presented in Table 2. The treatment simulated included filtration by a fine wire mesh and a fibre filter, followed by sedimentation and chlorination.

Referring to Table 2, the water quality check showed relatively unchanged $\mathrm{pH}$ of the water, an indicator of limited chemical changes to the used water. However, the reduction in turbidity was found to be significant, i.e. $65 \%$ drop. This is attributed to the effective dual-filter system adopted in the simulated treatment process. It is 
believed that in the actual SmartWUDHU' loop, turbidity can be further reduced with longer periods of sedimentation allowed in both the collection trough (at the ablution bay) and the elevated storage tank. As for disinfection, the introduction of chlorine has effectively eliminated hazardous biological contaminants, as shown by the below detection total coliform and E-Coli contents in the treated water sample. Finally, the slight increase in residue and total chlorine post-treatment was found to be within acceptable levels. Overall, for all the parameters examined, the treated ablution water was found to be in compliance with permissible levels of the Malaysian National Drinking Water Quality Standards.

Table 2. Water quality check: before and after treatment

\begin{tabular}{cccccccc}
\hline \multirow{2}{*}{ Parameter } & \multirow{2}{*}{ Units } & \multicolumn{2}{c}{ Untreated } & \multicolumn{2}{c}{ Treated } & \multirow{2}{*}{ Standard* } & \multirow{2}{*}{ Acceptable } \\
\cline { 3 - 6 } & & Mean & S.D & Mean & S.D & & \\
\hline pH & - & 6.64 & 0.12 & 6.90 & 0.17 & $6.50-9.00$ & Yes \\
Turbidity & NTU & 6.67 & 0.47 & 2.33 & 0.47 & $<5.00$ & Yes \\
Total coliform & MPN & $<50.00$ & - & Nil & - & Absent & Yes \\
E-coli & MPN & $<50.00$ & - & Nil & - & Absent & Yes \\
Residue chlorine & Mg/L & 0.26 & 0.03 & 0.42 & 0.08 & $0.20-5.00$ & Yes \\
Total chlorine & $\mathrm{Mg} / \mathrm{L}$ & 0.32 & 0.02 & 0.77 & 0.07 & $<1.00$ & Yes \\
\hline
\end{tabular}

*Reference: Malaysian National Drinking Water Quality Standards

\section{Conclusions and Recommendations}

The SmartWUDHU' demonstrates feasibility and practicality that can be implemented in conjunction with Islamic principles. The greywater recycling system is easy to install or retrofit, economical with simple fixtures required, reduces water wastage and helps conserve clean water supply. Although the current study is based on data collected a single source (i.e. the University's mosque), it is intuitive and logical to extrapolate the results to other similar house of worship for the Muslims. The estimation model, proposed extensive applications as well as water quality check results all point to a workable system. In a nutshell, greywater recycling may not be a novel idea, but SmartWUDHU' certainly is a practical incorporation of Islam, science and engineering worth implementing, as it embodies sustainable modern day living (no less an ibadah) with Islamic teachings.

\section{Acknowledgements}

The Authors would like to express their appreciation to all parties who have contributed to this study, especially Dr. Ust. Halimi Mohd Khalid.

\section{References}

Abd Hafiz, H. (2009). Personal communications, the University's mosque, Universiti Tun Hussein Onn Malaysia.

Abu-Rizaiza, O. S. (2002). Ablution Water: Prospects for Reuse in Flushing of Toilets at Mosques, Schools, and Offices in Saudi Arabia. King Abdul Aziz Univ. J., 14(2), 3-28.

Al Mamun, A., Muyibiand, S. A., \& Abdul Razak, A. (2013). Reuse potential of ablution water from IIUM Masjid. Proceedings of the International Conference on Biotechnology Engineering (ICBioE13), Kuala Lumpur, Malaysia.

Al-Bukhari. "The English Translation of Sahih Al-Bukhari." Translated by Muhammad Muhsin Khan, Al-Saadawi Publications, 1996, Volume 1, Book 4, Hadith 200.

Al-Wabel, M. I. (2011). Simple system for handling and reuse of gray water resulted from ablution in Mosques of Riyadh City, Saudi Arabia. Proceedings of International Conference on Environment Science and Engineering, IPCBEE vol.8 (2011), IACSIT Press, Singapore.

Bakir, H. (2001). Water demand management and pollution control: Key to securing and safeguarding the water supplies of MENA in the 21 $1^{\text {st }}$. Century. Retrieved August, 2010, from http://www.emro.who.int/Publications/CEHA-ESCWA.pdf

Center for the Study of the Build Environment, CSBE. (2003). A Report on Greywater Reuse in Jordan. 
Dixon, A., Butler, D., \& Fewkes, A. (1999). Water saving potential of domestic water reuse systems using greywater and rainwater in combination. Water Science and Technology, 39, 25-32. http://dx.doi.org/10.1016/S0273-1223(99)00083-9

Erikkson, E., Auffarth, K., Eileresen, A. M., Henze, M., \& Ledin, A. (2003). Household chemicals and personal care products as sources for xenobiotic organic compounds in grey wastewater .Water S.A., 29, 135-146.

Ibn Majah. "English Translation of Sunan Ibn Majah". Translated by Nasiruddin al-Khattab, Darussalam Publications, 2007, Vol. 1, Book 2, Hadith 425.

Loux, J., Winer-Skonovd, R., \& Gellerman, E. (2012, March). Evaluation of Combined Rainwater and Greywater Systems for Multiple Development Types in Mediterranean climates. Journal of Water Sustainability, 2(1), 55-77.

March, J. G., Gual, M., \& Orozco, F. (2004). Experiences on greywater re- use for toilet flushing in a hotel (Mallorca Island, Spain). Desalination, 164, 241-247. http://dx.doi.org/10.1016/S0011-9164(04)00192-4

My Metro. (2008). Tanya Pakar (Ask the Expert): Anda Musykil Dr.Mashitah Jawab (Your Doubts Answered by Dr. Mashitah): Berwuduk guna air musta'mal (Performing the ablution ritual with musta'mal water). Retrieved November 31, 2008, from http://www.hmetro.com.my/Current_News/myMetro/Sunday/ DrMashitah/20081130125753/Article/indexp_html

Pinto, U., \& Maheshwari, B. L. (2010). Reuse of greater for irrigation around homes in Australia: Understanding community views, issues and practices. Urban Water Journal, 7(2), 141-153. http://dx.doi.org/10.1080/15730620903447639

Prathapar, S. A., Ahmed, M., Al Adawi, S., \& Al Sidiari, S. (2004). Variation in quality and quantity of greywater produced at two mosques in Oman. Proceedings of the International Wastewater Conference, Salalah, Oman.

Rana, K., Shah, M., \& Upadhya, A. (2014). Integrated approach towards grey water management. International Journal of Engineering Sciences \& Research Technology, 239-242.

Singapore Islamic Council (Majlis Ugama Islam Singapura). (2007). Fatwa: Penggunaan air yang dikitar semula (Fatwa: The Use of Recycled Water) Retrieved January 14, 2009, from http://infad.usim.edu.my/modules.php?op=modload\&name $=$ News\& file $=$ article\&sid $=9750$

The Noble Qur'an. "English translation of the meanings and commentary, by Muhammad Taqi-ud-Din Al-Hilali and Muhammad Muhsin Khan". Madinah Munawwarah, King Fahd Complex for the Printing of the Holy Quran, 1983, (Al-A'raf, 7:31).

Tuan Ab Rahman, T.S. (2008). A case study of the local Islamic ablution system. Case Study Report, Faculty of Civil and Environmental Engineering, Universiti Tun Hussein Onn Malaysia, Malaysia.

Water Research Foundation. (1999). Residential end uses of Water. Denver, Colorado, USA.

Yahya, M., \& Fatchurrahman (1993). Dasar-Dasar Pembinaan Hukum Fiqh Islami (Policies for erecting Islamic Fiqh Laws). Bandung: PT. Al-Ma'arif.

Yousefi, B., Moazed, H., Pouladgar, M., \& Rahi, S. (2013). Review of gray water treatment and reuses for irrigation. Nature and Science, 11(2), 113-116.

\section{Copyrights}

Copyright for this article is retained by the author(s), with first publication rights granted to the journal.

This is an open-access article distributed under the terms and conditions of the Creative Commons Attribution license (http://creativecommons.org/licenses/by/3.0/). 